\title{
Identifikasi dan Penentuan Kadar Senyawa Fenol Pada Sedimen Tambak Di Kabupaten Sidoarjo
}

\author{
${ }^{1}$ Dede Sukandar*, ${ }^{2}$ Tri Heru Prihadi, ${ }^{1}$ Ai Faziah Hayati \\ ${ }^{1)}$ Program Studi Kimia Fakultas Sains dan Teknologi UIN Syarif Hidayatullah Jakarta \\ Jalan Ir. H. Juanda No 95 Ciputat 15412 Indonesia \\ 2) Balai Riset Kelautan dan Perikanan (BRKP) Jakarta Departemen Kelautan dan Perikanan RI \\ e-mail: ds_tea2007@yahoo.com
}

\begin{abstract}
Abstrak
Analisis terhadap kadar dan jenis senyawa fenol dalam sedimen tambak yang tercemar dan tidak tercemar oleh air lumpur Lapindo di Sidoarjo, Jawa Timur, telah dilakukan. Penentuan kadar senyawa fenol dilakukan dengan metode kolorimetri menggunakan reagen Folin Ciocalteau dan dianalisis dengan UV-Vis pada panjang gelombang $740 \mathrm{~nm}$. Kadar senyawa fenol yang terdapat dalam tambak tercemar dan tidak tercemar air lumpur Lapindo berbeda secara signifikan. Senyawa fenol lebih banyak terdistribusi pada tambak yang tercemar oleh air lumpur Lapindo. Kadar senyawa fenol yang terdapat dalam masing-masing sampel rata-rata $<1 \mathrm{mg} / \mathrm{L}$. Berdasarkan hasil analisis secara kualitatif dengan GC-MS, jenis senyawa fenol yang teridentifikasi adalah fenol, 4klorofenol, butilfenol dan metilfenol. Keempat senyawa tersebut merupakan jenis pencemar yang berbahaya bagi lingkungan perairan.
\end{abstract}

Kata kunci:: fenol, folin ciocalteau, GC-MS, kolorimetri, lumpur Lapindo, UV-Vis

\begin{abstract}
Determination of composition and amount of phenol compound has been done in embankment sediment which is polluted and unpolluted by Lapindo mudflow water in Sidoarjo, East Java. The measurement of total phenol has been carried out by colorimetry method with Folin ciocalteau reagent at $740 \mathrm{~nm}$. Phenol's content in polluted and unpolluted embankment are significantly different. It was found that phenol compound more distributed in polluted embankment by Lapindo mudflow water than unpolluted water. Phenol's content in each sample was less than $1 \mathrm{ppm}$ averagely. Based on the qualitative analysis result by GC-MS, each of phenol compound which were identified are phenol, 4-chlorophenol, buthylphenol, and methylphenol. Those four compounds are one of dangerous pollutan for water environment.
\end{abstract}

Key words : Phenol, Folin ciocalteau, GC-MS, colorimetry, Lapindo mudflow, UV-Vis

\section{PENDAhuluan}

Pada akhir bulan Mei 2006 lalu telah terjadi peristiwa meluapnya lumpur panas di Porong, Sidoarjo, Jawa Timur. Semburan lumpur panas tersebut berjarak 150-500 m dari sumur Banjar Panji-1 (BJP-1) yang merupakan sumur eksplorasi gas milik perusahaan tambang PT Lapindo Brantas Inc. (Anonim, 2006). Hingga saat ini semburan lumpur panas diperkirakan akibat dari aktifitas pengeboran yang dilakukan PT Lapindo Brantas di sumur tersebut.
Semburan lumpur panas dari dalam tanah terus mengalirkan lumpur pekat ke lahan milik warga. Menurut majalah Tempo yang terbit pada tanggal 12-18 Maret 2007, besarnya volume semburan sampai saat ini sudah mencapai $125.000 \mathrm{~m}^{3}$ per hari. Kerugian yang diakibatkan sudah mencapai jumlah yang sangat besar sehingga berbagai permasalahanpun muncul. Salah satu diantaranya berkaitan dengan perairan tambak yang letaknya tidak jauh dari lokasi semburan lumpur panas. Berdasarkan data dari Dinas Perikanan dan Kelautan Kabupaten Sidoarjo 
menyebutkan, bahwa tambak di Sidoarjo yang terancam lumpur Lapindo diantaranya di Kecamatan Porong seluas 493 hektare, Kecamatan Tanggulangin 496 hektare, dan Kecamatan Jabon 1.200 hektare.

Berdasarkan data yang dikutip dari Wikipedia, bahwa hasil pengujian terhadap kandungan lumpur yang dilakukan di tiga laboratorium (Sucofindo, Corelab, dan Bogorlab) menunjukkan adanya sejumlah senyawa kimia baik senyawa organik maupun anorganik. Diantara senyawa organik yang paling menonjol yang terdapat dalam lumpur dan air lumpur Lapindo adalah fenol dan triklorofenol. Bahkan berdasarkan hasil uji dari tim peneliti Badan Riset Kelautan dan Perikanan (BRKP) yang melakukan pengujian terhadap beberapa sampel air lumpur dari pond lumpur maupun rembesan dan air treatment, menunjukkan konsentrasi senyawa fenol di atas baku mutu yakni lebih besar dari $1 \mathrm{mg} / \mathrm{L}$ (BRKP, 2006).

Senyawa fenol merupakan salah satu bahan pencemar yang sering menimbulkan masalah di lingkungan. Bahkan menurut Dong et al., (1992) senyawa fenol merupakan jenis polutan yang berbahaya karena bersifat toksik. Senyawa fenol dalam perairan memiliki sifat racun terhadap organisme hidup seperti ikan yaitu pada kisaran $1000 \mu \mathrm{g} / \mathrm{L}$ untuk fenol, 200 $\mu \mathrm{g} / \mathrm{L}$ untuk kresol, $50 \mu \mathrm{g} / \mathrm{L}$ untuk 4-klorofenol, $15 \mu \mathrm{g} / \mathrm{L}$ untuk 2-klorofenol, dan $5 \mu \mathrm{g} / \mathrm{L}$ untuk 2,4-diklorofenol (Dojlido, 1993). Senyawa fenol lainnya yang juga beracun adalah penta klorofenol (PCP) (IPCS, 1995).

Fenol dikenal sangat reaktif terhadap jaringan tubuh manusia, dapat menyebabkan iritasi pada mata, hidung, dan tenggorokan. Fenol juga beracun terhadap sistem pernafasan dan dapat mengakibatkan rusaknya jaringan sistem saraf apabila termakan atau terhisap terus-menerus. Efek racun ini akan bertambah besar dengan banyaknya substituen yang terikat pada fenol terutama gugus klor (PUSARPEDAL, 2006).

Senyawa fenol seringkali dijumpai dalam lingkungan perairan yang berasal dari aliran air lumpur pemboran minyak bumi, buangan limbah rumah tangga, dan industri (Mulyono dkk, 1999).
Sehubungan dengan hal tersebut, kondisi pertambakan di Kabupaten Sidoarjo, khususnya yang berdekatan dengan lokasi semburan lumpur Lapindo memiliki potensi untuk tercemar oleh senyawa fenol yang berasal dari air lumpur.

Dinas Kelautan dan Perikanan Kabupaten Sidoarjo menyebutkan bahwa peristiwa semburan lumpur Lapindo secara tidak langsung berdampak pada pertambakan ikan dan udang terutama yang berada di Kecamatan Porong dan Jabon yang terletak di sebelah selatan dari lokasi semburan, serta di Kecamatan Tanggulangin yang terletak di sebelah utara dari lokasi semburan. Pertambakan di daerah tersebut dilewati oleh aliran sungai yang airnya sudah tercemar oleh air lumpur Lapindo. Berdasarkan data dari sumber tersebut, saat ini pertambakan di wilayahnya dapat dikatakan ada yang berstatus tercemar dan tidak tercemar.

Sedimen di pertambakan merupakan adsorben alami yang dapat mengikat jenis senyawa organik seperti senyawa fenol yang terkandung dalam air lumpur tersebut. Oleh karena itu, keberadaan senyawa fenol dalam sedimen tambak yang berada di Kabupaten Sidoarjo menjadi bahan pertimbangan untuk diteliti.

\section{METODE PENELITIAN}

\section{Eksperimen}

Ekstraksi dilakukan dengan alat ekstraktor soxhlet, penguapan pelarut menggunakan rotary evaporator Buchi, analis komposisi senyawa fenol dengan alat GCMS Merck Shimadzu QP 2010, dan analisa kadar senyawa fenol menggunakan spektrofotmeter UV-Vis Merck Perkin Elmer Lambda 25.

\section{Bahan Lumpur}

Sampel sedimen berupa lumpur yang diambil dari pertambakan yang tercemar dan tidak tercemar aliran air lumpur Lapindo yang berlokasi di Kecamatan Tanggulangin, Candi, dan Jabon, Kabupaten Sidoarjo Jawa Timur.

\section{Ekstraksi}

Sebanyak 20 gram sampel yang telah dimasukkan ke dalam thimble diekstraksi 
soxhlet menggunakan $100 \mathrm{~mL}$ pelarut metilen klorida $\left(\mathrm{CH}_{3} \mathrm{Cl}\right)$ selama 8 jam (ASTM , American Society for Testing and Materials, Nomor D.5369-93, 2003).

\section{Penentuan Kadar Fenol Total}

Penentuan kadar fenol total dalam sampel dilakukan dengan menguapkan pelarut (metilen klorida) dengan rotary evaporator sehingga diperoleh ekstrak fenol. Ditambahkan aquadest sampai $10 \mathrm{~mL}$ kemudian di vorteks selama 30 detik. Selanjutnya ditambahkan reagen folinciocalteau sebanyak $0,2 \mathrm{~mL}$ dan karbonattartrat sebanyak $2 \mathrm{~mL}$ dengan segera. Campuran di vorteks kembali dan kemudian dibiarkan pada suhu kamar atau ambient temperatur selama 30 menit (Widadi, 2005). Percobaan ini dilakukan dengan dua kali pengulangan, kemudian dianalisis dengan UVVis Merck Perkin Elmer Lamda 25 pada panjang gelombang $740 \mathrm{~nm}$.

\section{Identifikasi dengan GC-MS}

Ekstrak fenol diidentikasi menggunakan GC-MS Merck Shimadzu QP2010 pada kondisi kolom (Wall Coated Open Tubular (WCOT) panjang dan diameter kolom (30 m, $2 \mathrm{~mm}$ ), suhu injektor, detektor, awal kolom, dan akhir kolom $\left(200{ }^{\circ} \mathrm{C}, 250{ }^{\circ} \mathrm{C}, 120{ }^{\circ} \mathrm{C}\right.$, dan $\left.270{ }^{\circ} \mathrm{C}\right)$, suhu program kolom $\left(8{ }^{\circ} \mathrm{C} /\right.$ menit $)$, detektor (MS), gas pembawa (helium), dan laju aliran $(0,93 \mathrm{~mL} / \mathrm{menit})$.

\section{Analisis Data}

Data sebaran konsentrasi fenol total pada setiap lokasi dianalisis dengan menggunakan Analisis of Varians (ANOVA) satu arah dengan tingkat signifikansi 5\%.

\section{HASIL DAN PEMBAHASAN}

Data hasil perhitungan kadar fenol total dari masing-masing sampel dapat dilihat pada tabel 1. Berdasarkan hasil tersebut terlihat kadar fenol dari masing-masing sampel masih memenuhi persyaratan ambang batas maksimum konsentrasi fenol dalam lumpur kental, encer, dan cairan lumpur sesuai standar dari Kementrian Lingkungan Hidup (KLH) No.42 yakni sebesar $2 \mathrm{mg} / \mathrm{L}$.
Tabel 1. Kadar Fenol Total

\begin{tabular}{|c|c|c|c|}
\hline \multirow{2}{*}{$\begin{array}{l}\text { Status } \\
\text { Tambak }\end{array}$} & \multirow{2}{*}{ Sampel } & \multicolumn{2}{|c|}{$\begin{array}{c}\text { Kadar Fenol Total } \\
(\mathrm{mg} / \mathrm{L})\end{array}$} \\
\hline & & $\begin{array}{c}\text { Pengukuran } \\
\text { I }\end{array}$ & $\begin{array}{c}\text { Pengukuran } \\
\text { II }\end{array}$ \\
\hline \multirow{3}{*}{ Tercemar } & ST.Ii & 0,0935 & 0,0908 \\
\hline & ST.Ip & 0,0823 & 0,0810 \\
\hline & ST.Io & 0,0444 & 0,0375 \\
\hline \multirow{3}{*}{$\begin{array}{l}\text { Tidak } \\
\text { tercemar }\end{array}$} & ST.IIi & 0,0500 & 0,04305 \\
\hline & $\begin{array}{l}\text { ST.IIp } \\
\end{array}$ & 0,0388 & 0,0322 \\
\hline & $\begin{array}{l}\text { ST.IIo } \\
\end{array}$ & 0,0339 & 0,0297 \\
\hline \multirow{3}{*}{ Tercemar } & ST.IIIi & 0,0484 & 0,0422 \\
\hline & $\begin{array}{l}\text { ST.IIIp } \\
\end{array}$ & 0,0836 & 0,0776 \\
\hline & ST.IIIo & 0,0421 & 0,0362 \\
\hline \multirow{3}{*}{$\begin{array}{l}\text { Tidak } \\
\text { tercemar }\end{array}$} & $\begin{array}{l}\text { ST.IVi } \\
\end{array}$ & 0,0460 & 0,0424 \\
\hline & ST.IVp & 0,0281 & 0,0230 \\
\hline & ST.IVo & 0,0353 & 0,0327 \\
\hline
\end{tabular}

Data tersebut selanjutnya dianalisis dengan menggunakan uji Anova satu arah untuk melihat perbedaan antara tambak tercemar dan tidak tercemar air lumpur Lapindo. Hasil pengujian data masing-masing sampel diolah secara statistik dengan menggunakan uji Anova satu arah.

Hasil analisis data menunjukkan bahwa nilai $F$ yang diperoleh berdasarkan hasil perhitungan ( $\mathrm{F}$ hitung) sebesar 7,292 pada pengukuran I dan 6,483 pada pengukuran II. Sedangkan nilai $\mathrm{F}$ tabel dengan tingkat signifikansi $5 \%$ dan nilai df sebesar 10, adalah 4,96 (Nazir, 1985). Oleh karena $F_{\text {hitung }} \geq F_{\text {tabel }}$, maka hipotesis diterima. Artinya, terdapat perbedaan kadar fenol yang signifikan antara tambak yang tercemar dengan tambak yang tidak tercemar air lumpur Lapindo.

Keberadaan senyawa fenol di lokasi tambak tercemar tersebut diduga karena jarak tambak yang berdekatan dengan lokasi semburan lumpur Lapindo dimana sungai yang mengalir ke pertambakan tersebut juga sudah tercemar akibat lumpur dan air lumpur Lapindo (BRKP, 2006).

Selain itu, udara di kawasan pertambakan yang sudah tercemar akibat adanya semburan lumpur Lapindo juga bisa menjadi penyebab keberadaan senyawa fenol di pertambakan tersebut misalnya melalui proses deposisi. Karena perjalanan suatu zat kimia untuk bisa sampai ke bagian utama dari lingkungan biasanya mengikuti perubahanperubahan atau siklus alam melalui berbagai 
media seperti udara, air, tanah, dan rantai makanan (Mc.Kinney, 1981).

Analisa GC-MS dilakukan terhadap sampel pada ST Ii, ST IIi, ST IIIp, dan ST IVi yang memiliki kadar fenol tertinggi. Hasil analisa GC-MS untuk stasiun pertama (ST Ii) dapat dilihat pada kromatogram di bawah ini.

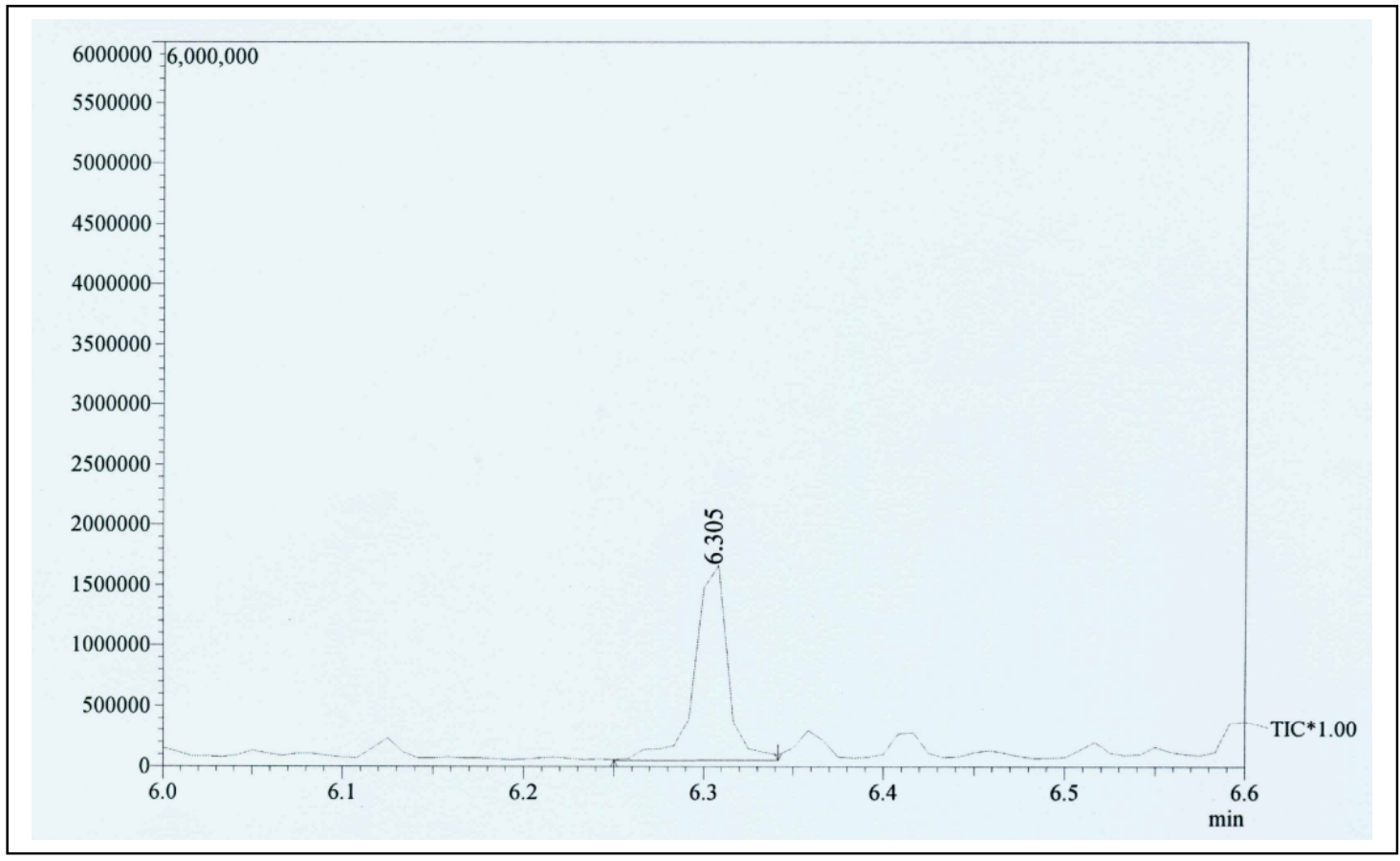

Gambar 1. Kromatogram Sampel pada ST Ii

Dari gambar 1 tersebut dapat diketahui bahwa pada ST.Ii terdapat senyawa 4klorofenol yang muncul pada waktu retensi 6,305 menit dengan $\mathrm{m} / \mathrm{z} 128$. Hal ini didukung dari hasil analisa MS yang menyatakan bahwa senyawa dengan $\mathrm{m} / \mathrm{z} 128$ adalah 4-klorofenol dengan nilai similarity index 96\% (Library : Wiley7) sebagaimana terlihat pada spektrogram berikut ini :

Hit\#:1 Entry:20181 Library:WILEY7.LIB

SI:96 Formula:C6 H5 CL 0 CAS:106-48-9 MolWeight:128 RetIndex:0

CompName:Phenol, 4-chloro- (CAS) p-Chlorophenol \$\$ 4-Chlorophenol \$\$ Phenol, p-chloro- \$ 4-Hydroxychlorobenzene \$\$ Appl

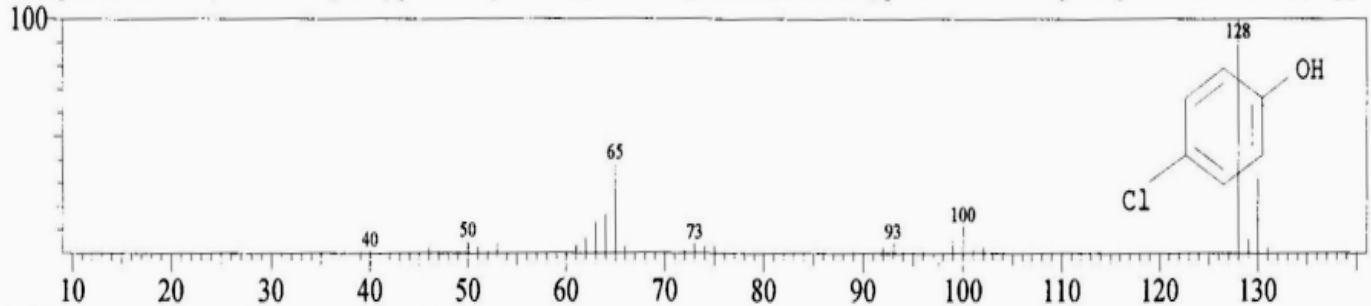

Gambar 2. Hasil Analisis MS 4-klorofenol

Sedangkan hasil analisa GC-MS untuk stasiun yang kedua (ST.IIi) dapat dilihat pada gambar berikut ini: 


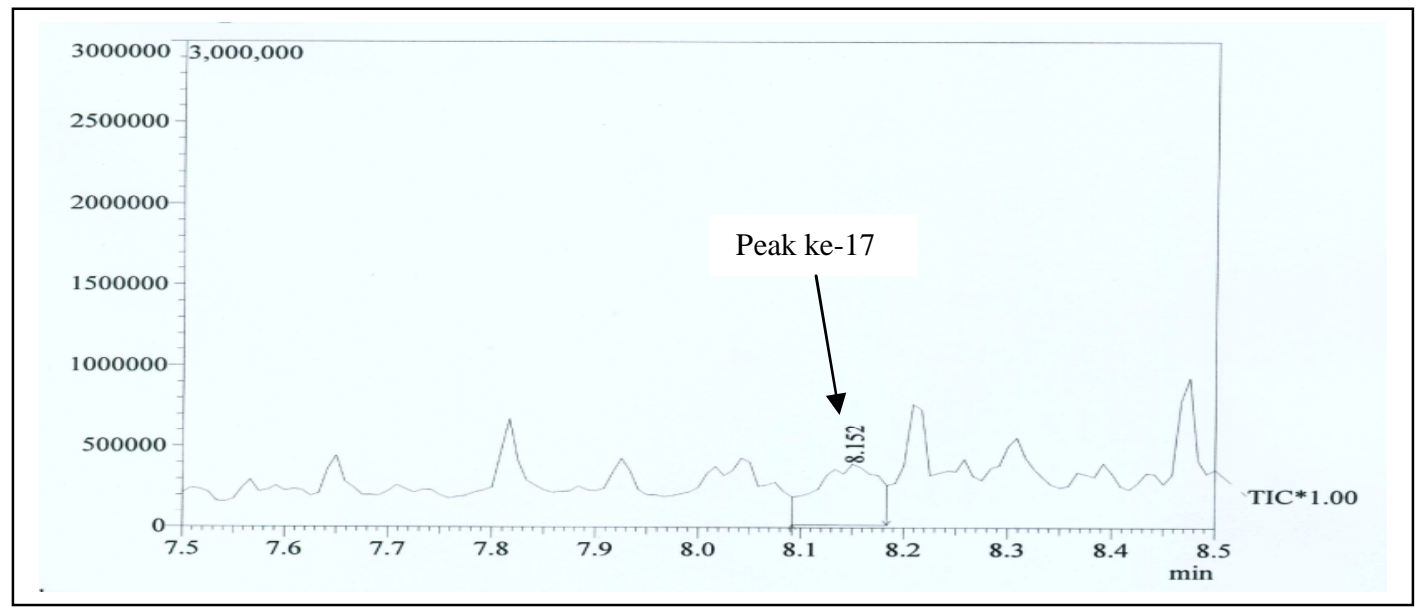

Gambar 3. Kromatogram Sampel ST.IIi

Dari gambar 3 di atas, dapat dilaporkan bahwa terdapat senyawa fenol tersubstitusi (peak ke-17) yang muncul pada waktu retensi 8,152 menit dengan $\mathrm{m} / \mathrm{z}$ 156. Selanjutnya, berdasarkan hasil analisa spektroskopi MS senyawa tersebut adalah 2-kloro-4,5dimetilfenol dengan nilai similarity index $95 \%$. (Library : NIST147).

\section{Hit\#:1 Entry:17496 Library:NIST147.LIB}

SI:55 Formula:C8H9ClO CAS:1124-4-5 MolWeight:156 RetIndex:0

CompName:2-Chloro-4,5-dimethylphenol \$\$ Phenol, 2-chloro-4,5-dimethyl- \$\$ Banol phenol \$\$ 2-Chloro-4,5-xylenol \$\$ 3,4-Dime

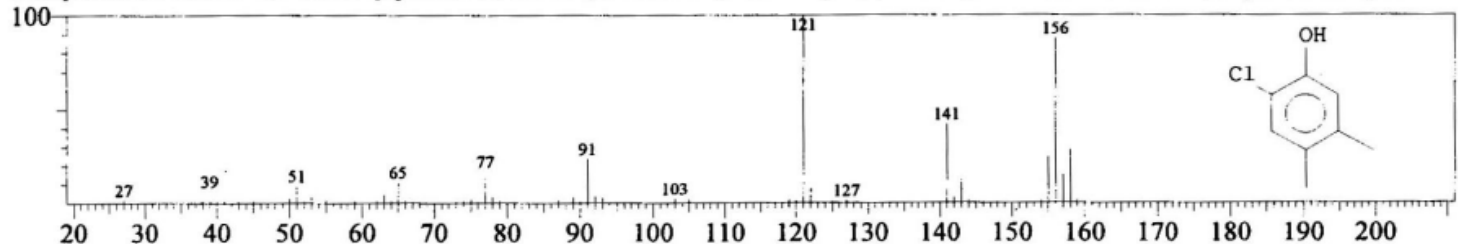

Gambar 4. Hasil Analisa MS Peak Ke-17

Hasil analisis GCMS untuk sampel ST IIIp dapat dilihat pada kromatogram berikut :

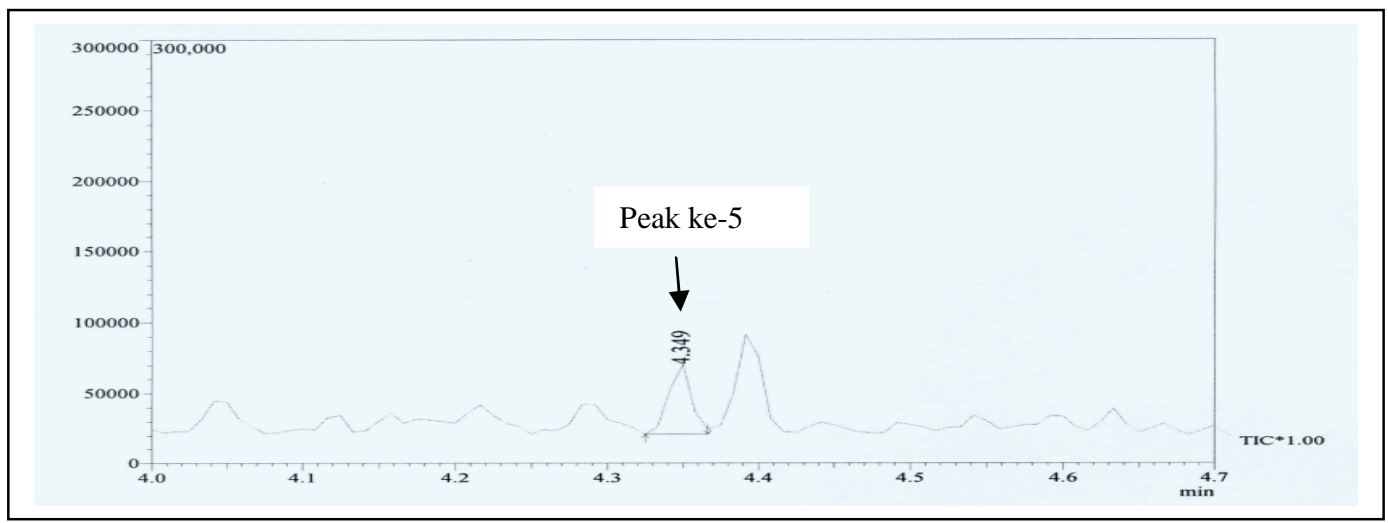

Gambar 5. Kromatogram Sampel ST.IIIp

Dari gambar 5 dapat diketahui bahwa pada ST.IIIp terdapat senyawa fenol (peak ke-
5) dengan waktu retensi 4,349 menit dan nilai similarity index $93 \%$ (Library : Wiley7). 


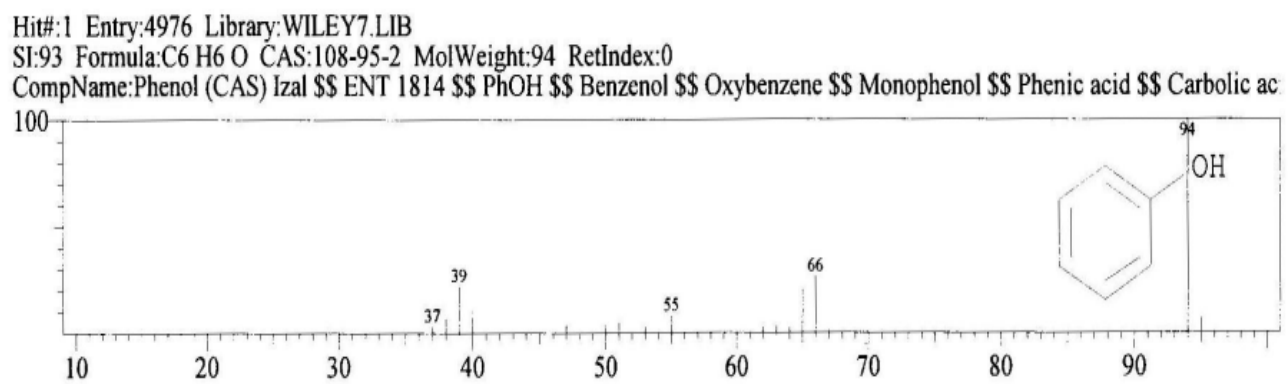

Gambar 6. Hasil Analisa-MS Peak Ke-5 Sampel ST.IIIp ini.

Hasil analisa GC-MS pada stasiun terakhir (ST.IVi) dapat dilihat pada kromatogram di bawah

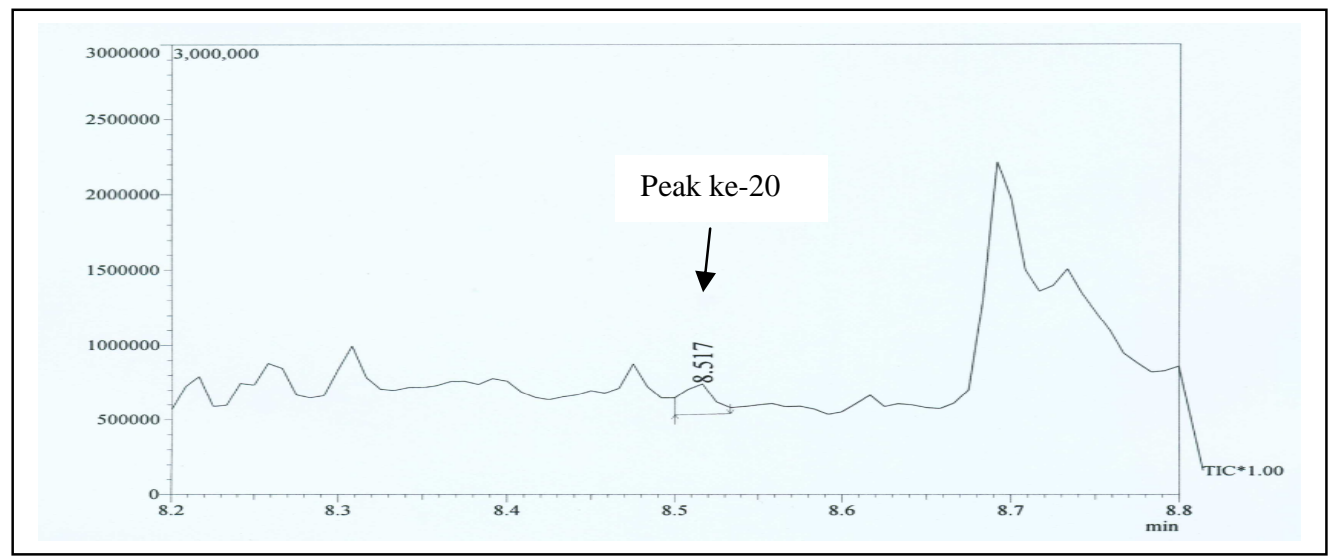

Gambar 7. Kromatogram Sampel ST.IVi

Dari gambar 7 di atas dapat diketahui bahwa pada pada sampel ST.IVi terdapat senyawa 4-metil-2,6-di-t-butilfenol (peak ke20) dengan waktu retensi 8,514 menit dan $\mathrm{m} / \mathrm{z}$ 220. Hal ini didukung dengan hasil analisa MS yang menunjukkan bahwa senyawa yang dimaksud adalah 4-metil-2,6-di-t-butilfenol dengan nilai similarity index $71 \%$ (Library:Wiley7).

Hit\#:2 Entry:121012 Library:WILEY7.LIB

SI:71 Formula:C15 H24 O CAS:128-37-0 MolWeight:220 RetIndex:0

CompName:Phenol, 2,6-bis(1,1-dimethylethyl)-4-methyl- (CAS) 4-Methyl-2,6-di-tert-butylphenol \$\$ BHT \$\$ P 21 \$ CAO 3 \$\$ A

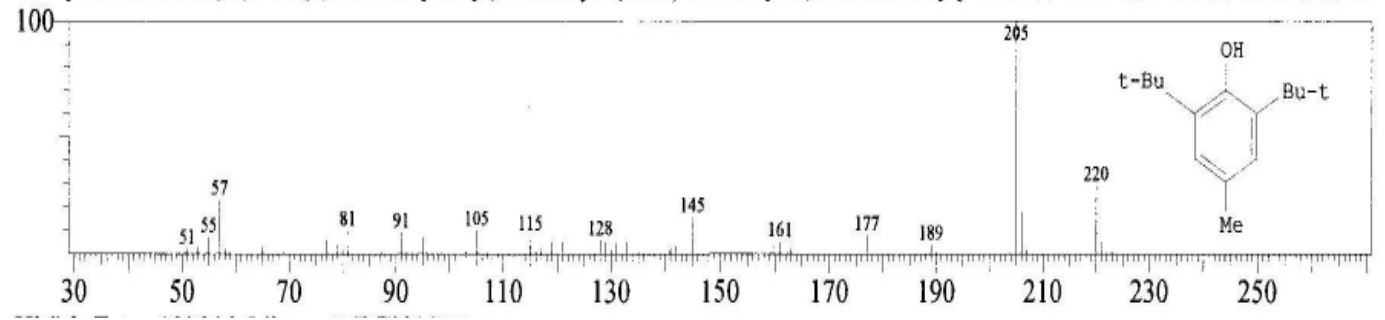

Gambar 8. Hasil Analisis MS Peak ke-20 Sampel ST.IVi 
Berdasarkan analisa data di atas, sedikitya terdapat 4 jenis senyawa fenol yang teridentifikasi pada tambak tercemar lumpur Lapindo, yaitu fenol, 4-kloro fenol, 2-kloro4,5-dimetilfenol, dan 4-metil-2,6-di-tbutilfenol.

Keempat Jenis senyawa fenol tersebut menurut Verschueren (1996) pada umumnya termasuk kelompok zat yang berbahaya dan beracun, sedangkan menurut Dong et.al. (1992) beberapa senyawa tersebut ternyata termasuk dalam kelompok zat yang karsinogenik bagi manusia. Selain terhadap manusia, menurut Dojlido (1993) senyawa organik seperti fenol dan 4-klorofenol juga beracun terhadap tubuh ikan yaitu pada konsentrasi $1000 \mathrm{ppb}$ untuk fenol dan $50 \mathrm{ppb}$ untuk 4-klorofenol.

Dengan teridentifikasinya senyawa fenol di dalam sedimen, besar kemungkinan dalam air tambak pun terdapat senyawa tersebut. Karena menurut Connell dan Miller (1985) sedimen merupakan absorben alami tempat bermukimnya pencemar-pencemar organik dari perairan. Sedangkan menurut Verschueren (1996) senyawa-senyawa tersebut dapat dikatakan stabil sehingga dimungkinkan keberadaanya ketika pertama kali dibuang ke lingkungan sama dengan ketika mereka berada dalam sampel penelitian.

\section{KESIMPULAN DAN SARAN}

Kesimpulan yang dapat diambil dari penelitian ini yaitu :

1. Sedimen tambak yang tercemar dan tidak tercemar air lumpur Lapindo mengandung senyawa fenol rata-rata $<1 \mathrm{mg} / \mathrm{L}$. Jenisnya adalah fenol, 4-kloro fenol, 2-kloro-4,5dimetilfenol, dan 4-metil-2,6-di-tbutilfenol.

2. Hasil analisis secara kuantitatif menunjukkan kadar senyawa fenol banyak terdistribusi pada tambak yang tercemar air lumpur Lapindo.

3. Kadar senyawa fenol pada tambak tercemar berbeda secara signifikan dengan kadar senyawa fenol pada tambak yang tidak tercemar air lumpur Lapindo dengan
Nilai $\mathrm{F}$ tabel pada tingkat signifikansi $5 \%$ $=4,96<$ dari nilai $F_{\text {hitung. }}$.

\section{Saran}

Pada dasarnya penelitian ini masih perlu pengembangan lebih lanjut. Oleh karena itu, peneliti menyarankan bahwa:

1. Sedimen beberapa tambak di Kabupaten Sidoarjo ternyata mengandung senyawa fenol, untuk itu perlu dilakukan monitoring terhadap zat-zat kimia yang terdapat pada pertambakan di wilayah tersebut terutama setelah terjadinya peristiwa semburan lumpur Lapindo.

2. Perlu adanya kerjasama dari pemerintah setempat untuk meminimalkan dampak yang terjadi setelah peristiwa semburan lumpur Lapindo terhadap pertambakan terutama yang berdekatan dengan lokasi semburan tersebut.

\section{UCAPAN TERIMA KASIH}

Terima kasih kami ucapkan kepada pimpinan dan staf Badan Riset Kelautan dan Perikanan Jakarta dan Kabupaten Sidoarjo yang telah mendanai dan membantu pelaksanaan penelitian ini.

\section{DAFTAR PUSTAKA}

1. Amerikan Society for Testing and Materials (ASTM), 2003, Standard Practice for Extraction of Solid Waste Sample for Chemical Analysis Using Soxhlet Extraction, ASTMAnnual Book of Standard, Vol 11.04. D. 5389-93, Philadelpia.

2. Anonim, 2006, Banjir Lumpur Panas Sidosrjo, http://www.wikipedia.org.

3. Badan Riset Kelautan dan Perikanan (BRKP), 2006, Analisis Kepekaan Lingkungan untuk Kesesuaian Lahan Tambak Melalui Teknologi $S I G$, Pusat Riset Teknologi Kelautan Badab Riset Kelautan dan Perikanan, Jakarta.

4. Connel, D.W., dan Miller, G.J., 1985, Kimia dan Ekotoksikologi Pencemaran, UI-Press, Jakarta.

5. Dojlido, J.R., 1993, Chemistry of Water and Water Pollution, Ellis Horwood, New York.

6. Dong, et.al., 1992, Molecular Cloning and Mapping of Phenol Degradation Genes from 
Bacillus Stearothermophilus FDTP-3 and Their Expression in Escherichia coli, Appl. Environ. Microbiol, 58 (8): 2531-2535.

7. Eaton, Clesceri, and Greenberg, 1995, Standard Methods for The Examination of Water, America: APHA.

8. International Programme on Chemical Safety (IPCS), 1995, Environmental Health Criteria 168: Pentaclorophenol, WHO.

9. Mc. Kinney, J.D., 1981, Environmental Health Chemistry, Ann Arbor Science, Michigan:

10. Mulyono, M., dkk., 1999, Jenis Senyawa Fenol dan Cara Penangulangannya di Dalam Air Terproduksi, Bulletin LEMIGAS, Vol.33 No. 32 Tahun 1999/2000.

11. Nazir, M., 1985, Metodologi Penelitian, Ghalia Indonesia, Jakarta.

12. Pusarpedal, 2006, Pedoman Prosedur Analisa Parameter Kunci, Deputi VII KLH dan JICA.

13. Verschueren, K., 1996, Handbook of Organic Chemical, International Publishing Company, USA, ed.3 hal.1801-1805.

14. Widadi, F.X., 2005, Identifikasi Senyawa Fenolik pada Ekstral Aloe vera, Fakultas Pertanian Universitas Tanjungpura, Pontianak. 